\title{
INCREASING SOCIETAL DISCOMFORT ABOUT A DOMINANT RESTRICTIVE PLANNING DISCOURSE ON OPEN SPACE IN FLANDERS/BELGIUM
}

Hans Leinfelder \& Georges Allaert

Department of Civil Engineering-Centre for Mobility and Spatial Planning, Ghent University, Ghent (Belgium)

\begin{abstract}
The specific spatial context in the densely urbanised northern part of Belgium, Flanders, offers a sort of laboratory conditions to study, design and plan fragments of open space in an urbanising context. A chronological analysis of documents in three periods relevant to Flemish spatial planning policy allows to conclude that one single planning discourse has reigned spatial planning in Flanders already since the design of the first zoning plans 45 years ago. This planning discourse considers city and countryside as two separate and separated entities. Today however, the validity of this dominant discourse is increasingly under pressure. An obvious societal need appears to be growing to turn around the perception of a possible contradiction between city and countryside. In a densely urbanised spatial context, alternative planning discourses should be based on the idea of open spaces that offer complementary services within a partnership between city and countryside.
\end{abstract}

\section{Introduction}

Flanders, the northern part of Belgium, is very densely urbanised. Approximately 70 percent of the Flemish population resides in an 'urban complex' - this is an area 
characterised by suburbanisation and by commuting to and from one of the nine Flemish urban agglomerations or Brussels. Only 10 percent of Flemish population lives in urban centres, the majority resides in a suburban environment. Even more striking is the area of land occupied per citizen in these urban complexes (see table 1). In Brussels, this ratio adds up to 0.53 ha per citizen. For other urban complexes in Flanders the ratio varies between 0.3 and 1.27 which illustrates an unrestrained suburbanisation process (see figure 1). (Kesteloot, 2003; see also Antrop, 2004).

Table 1. Area of land per citizen in urban complexes. (Kesteloot, 2003)

Figure 1. Urbanisation in Flanders. (Ministerie, 2004)

Already since centuries physical, economic, cultural and political factors lay the foundation for this fragmented Flemish spatial context (see Van Eetvelde \& Antrop, 2005; Van den Broeck, 2001; De Meulder \& Vandenbroucke, 2004). First, the extremely favourable soil conditions made and still make it possible to build almost everywhere at very low costs at this economic prosperous location in Europe, more specifically in the delta of the Scheldt river. Culturally, it is not only a historical dense network of medieval cities and major villages at an average $25 \mathrm{~km}$ large walking distance in between that is determining, There is also the mentality of the Flemish people, very keen on individual freedom, which is amongst others expressed in a quite omnipresent dream of an own 'house with garden'. Finally, the easy accessibility of the countryside was also consciously politically promoted through the development of a dense network of railways and roads in $19^{\text {th }}$ century to avoid concentrations of working class people in the industrialised cities. This was strengthened through governmental support of private ownership in the countryside - beneficially 
influenced by the catholic church - since living in smaller cities and villages was perceived as better in view of social, political and religious stability. Programmes were set up to provide in subsidies, cheap loans and profitable season tickets. In the second half of the $20^{\text {th }}$ century, the enormous growth in prosperity and jobs and the overwhelming success of individual car ownership only intensified the dynamics of this historical spatial fragmentation.

Despite this omnipresent network urbanity, Cabus (2001) estimates that 76 percent of Flanders still remains open. Gulinck \& Dortmans (1997) describe this open space as a mosaic of 'neo-rural fields' in an attempt to define it in a more positive and independent way than 'the space that remains open'. They consider neo-rural fields as contiguous and unbuilt geographical units at any location, as basic units for the strategic survey of resources in metropolitan areas and as building blocks for future land use and environmental planning. 'Neo-rural fields' also implicitly refer to the specific attention the more international concept of 'metropolitan landscape' pays to the (surrounding) countryside as it supports important urban ecological and cultural functions (see for instance Flores et al., 1998; Musacchio, 2008; and Joubert \& Limburg, 2009 for an application of the concept in the southern wing of the Randstad in the Netherlands).

Unfortunately this concept of 'neo-rurality' is a rare attempt in Flemish academic planning research - an attempt with a clear policy relevance since it contributed to the $2^{\text {nd }}$ Benelux Structure Scheme - to grasp the specific characteristics of open space in Flanders' spatial context. This is rather strange since the very extreme urban fragmentation, and as a logical consequence the far-reaching fragmentation of rural areas into open space fragments, makes Flanders a sort of internationally relevant laboratory to study, design and plan open space in urbanised and urbanising contexts. 
Where Sieverts (2003) searches for a more architectural and urbanistic approach of open space fragments, the final aim of my PhD-research (see Leinfelder, 2007) was to disrupt this academic silence in Flanders by introducing alternative concepts for the future regional planning of open space in urbanising contexts. To be able to embed these new concepts in a historical perspective, it was felt necessary to previously assess the way in which Flemish planning policy has tried to get grip on this growing fragmentation of open space, in the past as well as today.

The assessment exercise from the PhD-research and its results are the main topic of this article. A quite similar exercise has been made by Janssen (2006) for the southern part of the Netherlands, the region bordering Flanders, with a settlement structure resembling the Flemish one. The article reports on the research in a logical order. The first section describes the analysis of evolving planning discourses as a methodology to evaluate possible changes in planning policy. The second section gives an insight in the three periods in Flemish planning policy that were assessed more in detail on their planning discourses. The actual result of the research - the clear dominance of a single planning discourse on open space - is summarised in the third section. Finally, the last section elaborates on the decreasing relevance of this dominant discourse as observed by practitioners and scholars.

\section{Policy and planning discourses}

\section{Policy discourses}

Social-constructivist scholars in public management and political science conceive 'the' reality that policy makers try to grasp and direct as a social construction. Hajer (1995: 17; see also Dryzek, 1997) for instance states: "Any understanding of the state of the natural or the social environment is based on representations, and always 
implies a set of assumptions and (implicit) social choices that are mediated through an ensemble of specific discursive practices. Dynamics of [...] politics cannot be understood without taking apart the discursive practices that guide our perception of reality." This interest also explains why social-constructivist scholars are particularly keen on discovering the reasons why, in a certain political context, specific ways of looking at a problem gain importance and might eventually become dominant while others might fall into discredit. In order to get to the social and cognitive basis of this problem construction, the methodology of discursive analysis has been developed. It studies the interaction of societal processes that mobilise actors on certain themes on the one hand and on specific ideas and concepts that contribute to a common understanding of problems on the other hand. (Hajer, 1995) It is within this socialcognitive context that political decision-making takes place and policy measures are developed.

'Policy discourses' differ from other discourses such as everyday conversational discourses in the street or media discourses. Policy discourses are specific because of their political background of course, but also because of their normative character. While other discourses may contain normative elements, policy discourses hold in any way at least one normative element. (Boonstra, 2004) And it is exactly this normative character of policy discourses that is captured by the notion 'meaning' in the well known definition by Hajer (1995:4): “A specific ensemble of ideas, concepts and categorisations that are produced, reproduced and transformed in a particular set of practices and through which meaning is given to physical and social relations." A more specific definition of policy discourses has been developed by Arts et al. (2000: 63): 'dominant interpretative schemes, ranging from formal policy concepts to 
popular story lines, by which meaning is given to a policy domain'. (see also Healey, 2006)

Based on these two definitions, different scholars (Hajer, 1995; Van Tatenhove et al., 2000; Boonstra, 2004) distinguish three essential elements for the development of a policy discourse: the creation of a story line, the growth of a discourse coalition of actors and finally the institutionalisation in policy practices.

- A story line has to be understood as the creative narrative that enables actors to combine different notions, categories and story lines from very different policy domains and thus give meaning to specific physical and social phenomena. A story line suggests the creation of unity in the enormous variety of distinctive elements that determine a discourse about a certain problem or quality.

- Discourse coalitions of actors grow when previously independent policy practices and domains are actively connected, amongst others through story lines. In other words, a coalition emerges when existing policy practices get a meaning within a common political project. Actors in such a coalition can belong to different societal fields - politics, but also science, interest groups or media. But what unifies these actors and what gives them political strength, is that they all use the same story lines when they, independently of each other, engage in processes of political decision making.

- A discourse finally institutionalises when the story lines and the corresponding discourse coalitions are translated into policy practices: consolidation in policy and legislation or in the restructuring of a governmental organisation, ... Moreover, a discourse can eventually become 'dominant'. This happens when actors lose their credibility and are no (longer) a part of the coalition if they don't make use of the ideas, concepts and categories of this (dominant) discourse. The 
only way however to change policy is to question dominant policy discourses. Actions should break away from concepts, structures and ideas that merely last because of the need for continuity. (see Albrechts, 2006)

\section{Planning discourses}

As spatial planning is a specific policy domain, 'planning discourses' are specific policy discourses. It is not at all unlikely that Hidding et al. (1998) were inspired by Hajer when defining a planning discourse as a more or less coherent ensemble of ideas about the spatial organisation of society that is being constructed and reconstructed in an interaction between researchers, planners, designers, policymakers, politicians and interest groups. More recently, De Jong (2006) states that a planning discourse is about how societal groups and individuals look at and give meaning to their surroundings, but also about what they wish and hope for concerning their future living environment.

Also the three essential elements for the development of a policy discourse can be applied to planning discourses: the creation of conceptual complexes as specific kinds of story lines (Zonneveld, 1991), the growth of pluralistic planning communities - not only consisting of planners - concerning a certain planning discourse and, finally, the institutionalisation - eventually the dominance - of a planning discourse. These insights on the development of a planning discourse have already been profoundly illustrated by Faludi \& Van der Valk (1994) in their description of the Dutch planning doctrine in the $20^{\text {th }}$ century.

What is especially interesting about this theory on (planning) policy discourses is that it also offers a research method of discursive analysis of story lines, actor coalitions and institutionalisation methods in spatial planning. Moreover, when such an analysis is done in a historical perspective, it also gives insight in the succession of different 
planning discourses or in the rise and fall of dominant planning discourses over a longer period of time.

\section{Evolutions in planning discourses about open space in Flanders}

Important to know beforehand is that the object and the instruments of planning, and not the decision making dimension of planning, formed the core issue of my research on the way in which Flemish planning policy has tried to get grip on the growing fragmentation of open space (Leinfelder, 2007). As a consequence, the research primarily wanted to find answers on how Flemish society has looked at and has given meaning to the fragmented open space, what it has wished and hoped for concerning its development and how it has translated these wishes in legally binding documents and rules. In this way, the research consciously avoided the mainstream in (international and Flemish) planning research on planning processes and the different roles of actors in decision making. This explains why the research focussed on only two of the three elements in the development of a planning discourse: the evolution of the story line on the future development of (Flemish) open space on the one hand and evolutions in the institutionalisation of these story lines in planning practice on the other hand.

The planning discourses on open space in Flanders were reconstructed for three decisive moments or periods in Flemish planning policy: the design of the first zoning plans in the period 1960-1980, the development of the strategic policy document 'Spatial Structure Plan for Flanders' in the period 1980-2000 and the delineation of parts of the natural and agricultural structure since 2000 as part of the implementation of the structure plan. The evolution and possible dominance of story lines and planning discourses was assessed through a chronological analysis of all relevant 
(interim) studies, visionary and policy documents at national and regional (Flemish) level. The institutionalisation of discourses was approached in a strict sense through a research on the translation of the story lines in legal urbanistic rules and/or legal documents concerning these rules. The three periods cover an era of 45 years that has also been characterised by far reaching changes in agricultural policy. As a consequence the research did not only allow to answer the question if there was or were and still is or were one or more dominant discourses in Flemish spatial planning policy on open space. It was also possible to evaluate if there was an interaction between the planning discourse on the one hand and the agricultural policy discourse on the other hand.

Design of first zoning plans (1960-1980)

In the 1960s Belgian national government decided to design its first zoning plans. These sort of land use plans had to stop the chaos that had been created by the building permit policy of the first co-ordinated Belgian law on urbanism of 1962 as well as the lack of local planning initiatives. These zoning plans were originally conceived as rather informal directive plans, but finally ended up as legal land use plans, zoning and allocating at a scale 1/10.000 (figure 2). (Vermeersch, 1989) In the same period the germs of a newly 'unified' Europe tried to display themselves more explicitly, amongst others through the development of a common agricultural policy. This policy was predominantly inspired by the general wish to increase agricultural productivity in view of food security. At Belgian level this European aim was met by the introduction of the land consolidation instrument to structurally improve agricultural activity. 
Figure 2. Extract of a zoning plan (period 1960-1980) (dark colours: residential and industrial areas, light colours: agricultural and nature areas). (Ministerie, 2005)

The evolution of the story line throughout the design of the zoning plans was assessed by analysing the following documents (see table 2): the exploratory and searching working documents in the form of directive ('richtplan') and structure plans ('structuurplan') of the 1960s, the rough drafts ('voorontwerp'), the drafts ('ontwerp') and the final zoning plans at the end of the 1970s. The actual institionalisation of the story line and planning discourse only really became clear when the visioning process was progressively formalised in the rough drafts, drafts and final zoning plans.

Table 2. Design of zoning plans: source documents used for the assessment of story line and institutionalisation.

The policy documents in the design process of the zoning plans all stress the necessity of a politically made distinction between urban and rural society, with the open space as no more than a residual space for urban development. Furthermore, they show an explicit preference for (mono)functional zoning. As an intelligible reaction against the chaotic residential urbanisation in the preceding years, new residential, industrial and recreational developments were strictly allocated to specific areas, situated as much as possible in the urban fringe or in the proximity of existing villages. Complementary, the open space was completely safeguarded against these (more urban) developments. Furthermore the open space was subdivided in exclusive areas for agriculture, nature and forestry, amongst others to secure enough land for the economic development of agriculture. 
Due to a next phase in the Belgian constitutional reform in 1980 spatial planning policy became a Flemish competence. Determined to deal with the irrevocable first revisions of the zoning plans in a systematic way, Flemish government immediately decided in 1982 to prepare an overall visionary policy document on spatial planning a structure plan for Flanders. Two concept notes that define the framework for the development of the structure plan were produced in 1983 and 1984. But it was only in 1992 that a - academic and practitioners - planning group started the development of the story line of a 'Spatial Structure Plan for Flanders', finally approved by Parliament in 1997. (Ministerie, 2004) (see table 3 and figure 3) This Spatial Structure Plan for Flanders is a strategic visionary planning policy document that gives direction to planning initiatives of authorities at different policy levels (Albrechts, 1999). It is only through the delineation of parts of the agricultural and natural structure that the story line on open space and agriculture becomes institutionalised. (see further)

Table 3. Development of Spatial Structure Plan for Flanders: source documents used for the assessment of the story line.

Figure 3. Spatial Structure Plan for Flanders (period 1980-2000). (Ministerie, 2004)

In the period 1980-2000, due to the immense overproduction in agriculture on the one hand and the liberalisation of the global food market, the drastic and structural European MacSharry reform caused a gradual shift from a quite exclusive agricultural policy towards a combination of an agricultural and a rural policy. The Cork Statement in 1996 introduced the notion of 'rural development', institutionalised in 
Agenda 2000 in 1998, as a second 'rural development' pillar within the common agricultural policy. Since income stability and increased global competition of European agriculture are some of its main goals, it has to be said that Agenda 2000 rather seems to conceive the rural development policy as a compensation to farmers for the dismantled common agricultural policy. In a Flemish context, the land consolidation instrument was broadened through the introduction of landscape and recreational objectives and was, in the 1990s, partially replaced by land development as a new and multifunctional planning instrument.

The different planning policy documents in the development process of the Spatial Structure Plan for Flanders also stress the constant need for a politically made distinction between urban areas on the one hand and rural areas or the countryside on the other hand. The structure plan postulates the delineation of urban areas in a new type of zoning plans - implementation plans - as the appropriate way to consolidate or institutionalise this distinction. In other words, the delineation of the countryside should not be based on its proper characteristics; it will remain when the delineation of the urban areas has been completed. Within the countryside itself only vaster parts of the agricultural and natural structure should be delineated. Furthermore, the spatial development of the countryside should be planned in such a way that an unlimited economic development of the agricultural activity and the ecological development of the natural structure are safeguarded. As a consequence, other land uses, although often growing in societal importance - i.e. recreation - are not included at all in the spatial vision, or merely in a subordinate role. Actually the Spatial Structure Plan for Flanders expresses a striking negative approach of different kinds of new spatial developments in the countryside. It closes its eyes for the ongoing 'silent' metamorphosis of the Flemish countryside as De Roo \& Thyssen (1999) describe: 
every day old farm buildings are transformed into luxurious dwellings, small or medium firms, hotels, restaurants and other recreational businesses. Each of these transformations is itself small-scale, low-dynamic and thus 'silent', but the cumulative effect isn't and causes structural changes in the spatial configuration of the countryside.

\section{Delineation of parts of the agricultural and natural structure (since 2000)}

It was only in 1999, two years after the approval of the Spatial Structure Plan for Flanders, that the Flemish government took the first steps in the delineation of parts of the agricultural and natural structure as implementation of the policy document. This new delineation of agricultural areas in implementation plans was a necessary step since the structure plan implied a reduction with 56.000 hectares of the 806.000 hectares agricultural area on the zoning plans. This reduction is mainly in favour of new zones for nature and industrial development. Also, the implementation plans could be a vehicle to introduce more up-to-date urbanistic rules on the development and management of the delineated agricultural areas. A first phase of the process resulted in the delineation of 85.000 hectares natural areas (70 percent of the objective). The delineation was based on a GIS-overlay of a vision on the spatial development of nature on the one hand and an inventory of the actual agricultural land use on the other. In practice, this political compromise proved to be nothing more than a confirmation of the already 'green' areas in the original zoning plans of the 1970s. The urge of the nature policy domain and the fear for a societal and political polarisation between nature and agriculture made government reach for simple, objectified methodologies and avoid more complex and more normative decision making. (Custers et al., 2003) In 2003 Flemish government finally decided to end this mechanistic planning process and to develop integrated spatial visions on nature and 
agriculture at a regional scale as a basis for the delineation (figure 4). These planning processes took and still take a lot of time however, not only to discuss the spatial vision but especially to translate the vision into the implementation plans. In order to speed up the delineation process, Flemish government invented the simple technique to 'reconfirm' agricultural areas of the original zoning plans. Reconfirmation consolidates by resolution, not by zoning or land use planning, the validity of these zones from the 1970s, without adding any up-to-date urbanistic development or management rules. At the end, the technique of reconfirmation will probably be implemented on 60 percent of the 750.000 hectares agricultural area to be delineated. (table 4)

Table 4. Delineation of parts of the agricultural and natural structure: source documents used for the assessment of the story line and institutionalisation.

Figure 4. Extract of the spatial vision for the delineation of parts of the agricultural and natural structure (period since 2000)

Where Flemish spatial visioning for the countryside only evolved slowly since 2000, European agricultural policy increasingly changed - especially in words - into rural policy. Based on the experiences in the first rural development program 2000-2006, the new program 2007-2013 distinguishes three rural development pillars besides the one, still remaining agricultural pillar. However, later decisions to decrease the budget for rural development put serious question marks to these options.

Since the delineation of urban areas and of parts of the agricultural and natural structure is an implementation of the Spatial Structure Plan for Flanders, most of the observations on the story line about the spatial development of open space are similar 
to the ones already described: a continuing fear for new developments in the countryside and a prominent economic approach of agriculture. The politically made distinction between urban areas and the countryside is institutionalised in implementation plans as a boundary around urban areas. A similar boundary around the countryside based on its proper qualitative characteristics is missing: only the areas functionally relevant to agriculture and nature are delineated. Finally the reconfirmation of agricultural areas contributes merely to the quantitative objective of delineating the total surface in agricultural use, but does not at all imply a substantive qualitative addition. The reconfirmation does not create the necessary conditions to develop open space or agricultural areas in a way they could take up a structural role within the urbanising spatial context and shouldn't be artificially safeguarded through a legal plan.

\section{A dominant discourse in Flemish spatial planning on open space and agriculture}

The chronological analysis allows to conclude that a planning discourse considering city and countryside - urban areas and rural areas - as functionally and morphologically separate entities has reigned spatial planning in Flanders already since the design of the first zoning plans 45 years ago. Simultaneously this dominant planning discourse seems to have coincided with a rather economically biased planning discourse on agriculture. The next paragraph describes how, 45 years ago, this planning discourse was clearly embedded in an overall societal belief in and focus on the city as the place for development. But, the paragraph also shows that, today, the spatial and societal context no longer coincide with this discourse. The dominant discourse ignores, in other words, the mixed multidimensional reality of city and countryside. 


\section{City and countryside as separate entities}

Since the period 1960-1980 is dominated by an overall societal ambition of welfare growth, the original zoning plans provide all necessary spatial conditions to transform the traditional-rural society into an urban-industrialised one. The development of urban areas/cities is considered superior to this of the rural areas/countryside. Spatial planning of open space is only treated in second order. The rough draft of the zoning plans doesn't try to hide that the open space is only that space that doesn't qualify for the development of more urban land uses such as residential, economic and recreational activities. This explains why the 'rural area' ('landelijk gebied') on the rough drafts is nothing more than a residual space, a literally blank area without any colour referring to the land use aimed for. Moreover, the corresponding urbanistic rule states that the existing vegetation and arrangement of the 'rural area' define whether the zone should be legally considered as agricultural, forest or nature area ... hereby implicitly admitting that a coherent and anticipating vision for the open space is really missing.

The story line on open space in the development of the Spatial Structure Plan for Flanders in 1980-2000 suggests a more balanced and complementary approach of 'cities' and 'countryside'. The analysis in the structure plan of the spatial context confirms the existence in Flanders of a mixed reality, a so-called 'urban conglomerate' characterised by fragmentation. At the same time, it optimistically underlines the existence of some urban nodes and some vaster peripheral open spaces. The dissatisfaction with the chaotic suburbanisation in the preceding period and the unease to cope with the spatial implications of network society however result in a political urge to make a strict distinction between an urban area policy and a countryside policy. As a consequence, the spatial vision of the plan, 'Flanders, open 
and urban' ('Vlaanderen, open en stedelijk'), implies a deconcentrated clustering of new developments in urban areas and major rural villages in favour of the spatial extension or conservation of nature, agriculture and forestry elsewhere (Albrechts \& Lievois, 2004). It appears that, at a moment where the actual differences between city and countryside seem to fade, the societal and political need to protect and to strengthen the identity of the countryside grows: or, in other words, the more city and countryside intermingle the greater the desire to distinguish them politically. (De Roo \& Thissen, 1999)

This even becomes more obvious in the implementation of the structure plan. The planning discourse of city and countryside as separate entities is institutionalised in the form of borderlines around urban areas in the implementation plans subsequent to the Spatial Structure Plan for Flanders. By delineating the urban areas, the countryside becomes delineated too. This observation implies that the Flemish policy document does not all envisage the institutionalisation of an explicit vision on the development of the countryside as a spatial entity. Where the concept of the structure plan in 1993 still mentions an open space with specific natural and landscape characteristics, the final structure plan in 1997 the countryside brings it back to a compilation of spatial structures related to specific land uses - the natural structure, the agricultural structure and the settlement structure. Furthermore, the delineation process of parts of the agricultural and natural structure is a very introvert planning exercise. Spatial visions for countryside regions within the densely urbanised centre of Flanders completely ignore the mix of urban and rural land uses. Or they indirectly allude on the urbanisation in a negative, repressive way. An economically strong agricultural activity is still considered as the best guardian of the landscape against the intrusion of other land uses and against the transformation of open space into private gardens. The 
question is how long this approach of the countryside will survive in an urbanised and urbanising spatial context such as the Flemish one where other land uses increasingly determine the future spatial development of the countryside. Anyhow, approaching the delineation of parts of the agricultural and natural structure as a pure countryside topic seems to have become too narrow as a satisfactory planning answer. (Leinfelder, 2005) The problem is however situated at the highest level of the Spatial Structure Plan for Flanders since any alternative vision on open space in the Flemish urbanising spatial context is missing in the planning document.

\section{Geographical and historical context}

The observation on this dominant discourse on open space is not unique for Flemish spatial planning policy. Characteristic for instance for Great Britain's spatial planning policy is the strong conservationist attitude towards the countryside. Originally fed by aristocracy obsessed by fox hunting, it has crystallised in a public unanimous feeling about the need for plans protecting the countryside. This opinion is nowadays strategically exploited by NIMBY-adepts that react against all kinds of developments in the immediate surroundings of their dwellings. It has also been institutionalised in legislation: the 'Agriculture Act' and 'Town and Country Planning Act', both dating from 1947. (Newby, 1996) Mac Farlane (1998:188) notes as a result of an enormous manifestation of thousands of countryside dwellers in London March $1^{\text {st }}$ 1998: "The rural is a category of thought. The countryside is not a place, it is an idea." Also Dutch spatial planning shares with the Flemish one the objective to indirectly safeguard the open landscape of the rural areas through the promotion of urban densification. In a similar way as in my research on Flemish spatial planning, several Dutch scholars have observed that a traditional, dichotomous and static image on city 
and countryside has dominated the debates in the Netherlands and has led to a very introvert discourse. (see Hidding et al., 1998; De Vries, 2004)

One could argue that this discourse of city and countryside as separate entities, with the delineation of urban (development) areas as its institutional dimension, is primarily inspired by a need to control building activities. The European knowledge exchange project RURBAN however puts the dominance of this antipode perception of the relationship between city and countryside in North-West-Europe in a broader cultural perspective. (Overbeek, 2006). A historical rural tradition with a central role for agriculture and/or nature explains why Flemish, British and Dutch societies value the countryside as positive and city and urbanisation as negative. This also explains the political option to 'limit' urban extension and to 'safeguard' open space for agriculture and nature. Oppositely, in for instance the more Mediterranean rural tradition, the countryside is perceived as negative and, in contrast, city and urbanisation are considered as positive since the latter imply economic development. Derks (1986, in: Hidding et al., 1998) defines the early roots of this north-westeuropean dominant planning discourse in two parallel $19^{\text {th }}$ century phenomena: on the one hand the industrial revolution as a primarily urban phenomenon and, on the other hand, an evolution in agriculture to produce food for abroad and no longer, according to von Thünen's logic, for the nearby city. As a result the economic gap between city and countryside grew while mutual dependency decreased. Since the continuing industrialisation also determined $20^{\text {th }}$ century scientific development, the discourse of city and countryside as antipodes also became scientifically institutionalized. Already since the 1940s, all around the world, the research on data, trends and prognoses - for instance of demographic evolutions - is divided in 'urban' and 'rural' disciplines. (Champion \& Hugo, 2004) It is striking how Gulinck \& Dortmans (1997) correctly 
note that the most commonly used asset to distinguish city and countryside is 'population density' and that this is essentially an urban feature what again implies a negative way of defining the countryside. At the same time the authors subtly observe that the OECD-threshold of 150 inhabitants per square kilometer implies that there is no (more) countryside left in Flanders.

During the twentieth century the original economic difference between city and countryside has become an intuitive and multidimensional difference. It involves a morphological dimension expressed in differences in typologies of dwellings, in density of dwellings and in population density. The distinction is also functional since it refers to the difference in speed and character of developments in both entities. It has a socio-cultural dimension, for instance the difference between the introvert rural village community and the open and anonymous city life. Also ecologically, there is 'nature in and on the built environment' and there is 'wild nature'. And it finally involves a symbolic dimension when attempts are made to grasp and influence societal processes in their spatial dimensions by making a conscious distinction between city and countryside. (Asbreek Brusse et al., 2002)

A planning discourse that considers city and countryside as separate entities also implies a stringent and hierarchical application of pattern concepts. The discourse often refers to a rather static, artificial and morphological interpretation of spatial structures and historical patterns in the use of space that is imposed top-down. Illustrative are popular concepts in Dutch planning practice that try to cluster new developments within or in the proximity of the delineated city: 'compact city' at a local scale, 'city region' at a regional scale and 'clustered deconcentration' at a national scale. Other often used concepts for the countryside - such as 'restrictive policy' - aim for the conservation of the existing spatial conditions. In reality 
however, this conceptual focus is mainly translated very quantitatively in planning practice as to obstruct urbanisation processes through more classical regulatory instruments - defining contours or borderlines and allocating quota for new houses at the cost of stimulating quality in the countryside. Zonneveld (1999) even considers the concept of 'compact city' as a sign of weakness because of its defensive character. For him, it does not at all express a vision on the coherent development of city and countryside, it tries to stop developments, to defend the countryside against urbanisation.

Finally, the planning discourse of city and countryside as separate entities and thus the planning discourse on open space seems to fit seamlessly to a planning discourse that guarantees sufficient spatial development possibilities for agriculture as a merely economic activity. The countryside/open space is simply equated with agriculture and agriculture, with or without financial support, is and remains the economic fundament for the traditional way of life at the countryside. (Newby, 1996) Since the lack of dynamism is considered as the main problem of the countryside, agriculture has no other challenge than to modernise although, simultaneously, there is an obvious fear that this could also result in too much dynamism. This planning discourse on agriculture also ignores reality, since more and more farmers search for an increase of their income through the expansion of their activities besides strict farming: subsidized landscape and nature care, leisure provision, direct selling of regional and biological products. (see for a detailed analysis: van der Ploeg, 2000 and van der Ploeg et al., 2002)

\section{Decreasing relevance of the dominant planning discourse}


After 40 years the validity of the conceptual complex of the dominant planning discourse of city and countryside as separate entities is increasingly under pressure. There is an obvious societal need to turn around the perception of the contradiction between city and countryside: from a vision in which urban development penetrates the countryside towards a vision in which the entire space, city and countryside, is needed for people's material and psychological development. By definition, urbanised areas, to survive, always had to rely on the resources of the surrounding countryside. The capacity to support urban growth has always been in the countryside. (Holliday, 1994 and 1997) It is worth mentioning that, already in 1999, one of the policy aims of the European Spatial Development Perspective (Committee, 1999) was to enhance urban-rural partnerships to overcome outdated dualisms between city and countryside and to stress the benefits of greater rural-urban integration. (see Briquel \& Collicard, 2005; Faludi and Waterhout, 2002)

Problematic however is that 'urban' and 'rural' have become almost untouchable words, as well in a professional planning context as in daily life. The majority of the people is still convinced that they feel a difference between city and countryside. Since they define city and countryside as real, they are real in their consequences. People reproduce space through actions based on these two spatial categories. This observation does not at all imply that government is still allowed to or should produce these symbolic spaces physically and socially. Reality is that city, as a morphological phenomenon, and urbanity, as its societal counterpart, are increasingly present in the countryside. And, in this open space, traditional agriculture and rurality seem to loose their dominance day by day. Or in other words, where a dichotomous political approach of city and countryside still suggests separation, the mix in reality of urban and rural functions and activities is a fact. How much the Spatial Structure Plan for 
Flanders tries to cluster new activities and to protect openness in a sustainable way, a wide variety of individual initiatives combined with a very flexible building permit regulation result in a completely different reality. If countryside is described as that what remains when the urban areas are delineated, undoubtedly severe substantial problems occur when urban phenomena, as today, are no longer embedded in vast spatial and definable fragments. And the most important criticism finally, this planning approach totally ignores the multiplicity in roles the countryside fulfills today and will fulfill in the future within an urbanising society. This multiplicity in roles in its turn could be a valuable argumentation for a delineation of the countryside from the perspective of the countryside, but now as a specific part within the urban conglomerate. In this context, Kerkstra (2004) wonders whether or not spatial development should rather be considered as a superposition of continuous spatial systems that mutually penetrate and interfere instead of as a juxtaposition, an arrangement of city and countryside next to each other.

Summarised, there seems no more solid physical, social or cultural repertory left that allows to link one-to-one functions, activities or land uses to predicates such as 'urban' or 'rural'. The concepts that form the discourse and that describe the relation between city and countryside as one-dimensional are no longer capable of embodying the new, so-called 'relational geography' in contemporary society: relationships betweens places and activities have become very complex and deal with several spatial scales. This also implies that proximity has become less important in the organisation of society. Zonneveld \& Verwest (2005) observe that this wouldn't be the last time that a spatial concept would lose importance because of a switchover in societal relationships from proximity to attainability. The use of two simple categories 'city' and 'countryside' ignores any complex and multi-layered spatial reality. For 
some good reason, in recent years partners of several Interreg-projects are constantly in search for a new vocabulary to address city and countryside: see for instance SAUL (Sustainable and Accessible Urban Landscapes; www.saulproject.net), PURPLE (Peri-Urban Regions Platform Europe; www.purple-eu.org), RURBAN (Building new relationships in rural areas under pressure; www.rural-urban.org) and SOS (Sustainable Open Spaces; www.sos-project.org)

\section{Conclusions}

The paper has extensively described a chronological analysis of Flemish planning documents in three periods, covering the last 5 decades. This analysis has shed light on the dominance of one single planning discourse on the relation between city and countryside and simultaneously on the role of open space and agriculture. All the time, city and countryside have been considered as functionally and morphologically separate entities. Open space or the countryside is the residual space, in the first period just empty and waiting to be urbanised, in the more recent period increasingly considered as an equivalent of the built area, the city, but still defined as the space that remains after preserving sufficient spatial development possibilities for urban functions and activities.

The paper has also extracted thoughts from mainly contextual North-West-European literature to illustrate that this planning discourse has presumably reached its expiration date already. More and more scholars plead for inspiring alternatives. De Roo et al. (1999) as well as Overbeek \& Terluin (2005) suggest for instance a more territorial or region-oriented approach of open spaces in which all actors involved in an open space formulate a vision on how to deal with claims of all different land uses, based on the present qualities, problems and potentials of the open space. This implies 
a bottom-up, integrated, differentiated and region-specific policy, regardless of the fact that this open space is confronted with urban or rural problems. In such an approach, open spaces offer complementary services within a partnership between city and countryside and no longer from an isolated countryside perspective. "The advantage of the new decentral view is that it presupposes a positive function of rural landscapes, based on uses and perceptions by people, which may create more opportunities to identify win-win-situations between different groups of actors." (Overbeek \& Terluin, 2006: 33)

\section{References}

ALBRECHTS, L. (1999). Planners as catalysts and initiators of change. The new Structure Plan for Flanders. European Planning Studies, 5, pp. 587-604.

ALBRECHTS, L. (2006) Dynamic visioning: a catalyst for change?, paper at the $2^{\text {nd }}$ World Planning Schools Congress 'Planning for diversity and multiplicity: a new agenda for the world planning community', Global Planning Education Association Network, Mexico City, July 12-16 2006.

ALBRECHTS, L. \& LIEVOIS, G. (2004). The Flemish Diamond: urban network in the making? European Planning Studies, 3, pp. 351-370.

ANTROP, M. (2004). Landscape change and the urbanization process in Europe. Landscape and Urban Planning, 67, pp. 9-26.

ARTS, B., VAN TATENHOVE, J. \& LEROY, P. (2000) Policy arrangements, in: J. VAN TATENHOVE, B. ARTS \& P. LEROY (eds.) Political modernisation and the environment, the renewal of environmental policy arrangements, pp. 53-69. Dordrecht: Kluwer Academic Publishers.

ASBEEK BRUSSE, W., VAN DALEN, H. \& WISSINK, B. (2002) Stad en land in een nieuwe geografie, maatschappelijke veranderingen en ruimtelijke dynamiek. 
Wetenschappelijke Raad voor het Regeringsbeleid, voorstudies en achtergronden nr. 112. Den Haag: Sdu Uitgevers.

BOONSTRA, F. (2004) Laveren tussen regio's en regels, verankering van beleidsarrangementen rond plattelandsontwikkeling in Noordwest Friesland, de Graafschap en Zuidwest Salland. Assen: Koninklijke Van Gorcum.

BRIQUEL, V. \& COLLICARD, J.J. (2005). Diversity in the rural hinterlands of European cities, in: K. HOGGART (ed.) The city's hinterland, dynamism and divergence in Europe's peri-urban territories, pp. 19-40. Aldershot: Ashgate CABUS, P. (2001) Nood aan een nieuw stedelijk model? De compacte stad onder vuur. Ruimte \& Planning, 1, pp. 2-8.

CHAMPION, T. \& HUGO, G. (2004) Introduction: moving beyond the urban-rural dichotomy, in CHAMPION, T. \& HUGO, G. (eds.) New forms of urbanisation, beyond the urban-rural dichotomy, pp. 3-24. Aldershot: Ashgate.

COMMITTEE ON SPATIAL DEVELOPMENT (1999). ESDP, EUROPEAN SPATIAL DEVELOPMENT PERSPECTIVE. Luxembourg: Office for Official Publications of the European Communities.

CUSTERS, S., LEINFELDER, H. \& VANDEVOORT, C. (2003) Afbakening van natuur en landbouw in Vlaanderen: een nauwe trechter en een lelijke mozaïek, in: P. SCHRIJNEN (ed.) De cultuur van het bestuur, over Nederlandse trechters en Vlaamse mozaïeken, discussiebijdragen. Delft: Stichting Planologische Discussiedagen.

DE JONG, M. (2006) Imaginations for regional design, seeking for new concepts, visions and strategies for regional developments, paper at the $2^{\text {nd }}$ World Planning Schools Congress 'Planning for diversity and multiplicity: a new agenda for the 
world planning community', Global Planning Education Association Network, Mexico City, July 12-16 2006.

DE MEULDER, B. \& VANDENBROUCKE, T. (2004) Het Leie-Scheldeinterfluvium: theater van de bricolage, Oase, 63, pp. 110-139.

DERKS, H. (1986) Stad en land, markt en oikos. Doctoraatsproefschrift. Amsterdam: Universiteit van Amsterdam.

DE ROO, N. \& THISSEN, F. (1999) Nieuwe beelden van het Vlaamse platteland, in: N. DE ROO, F. DE RYNCK \& S. VANDELANNOOTE (eds.) De stille metamorfose van het Vlaamse platteland, pp. 17-41. Brugge: Die Keure.

DE VRIES, J. (2004) Private ruimtelijke strategieën, Stedenbouw \& Ruimtelijke Ordening, 3, pp. 6-9.

DRYZEK, J. (1997) The politics of the earth, environmental discourses. Oxford: Oxford University Press.

FALUDI, A. \& VAN DER VALK, A. (1994). Rule and order, Dutch planning doctrine in the 20th century. GeoJournal Library 28. Boston: Kluwer Academic Publishers.

FALUDI, A. \& WATERHOUT, B. (2002). The making of the European Spatial Development Perspective: no masterplan. London: Routledge.

FLORES, A., PICKETT, S., ZIPPERER, W., POUYAT, R. \& PIRANI, R. (1998). Adopting a modern ecological view of the metropolitan landscape: the case of a greenspace system for the New York City region, Landscape and Urban Planning, 4, pp. 295-308.

GULINCK, H. \& DORTMANS, C. (1997) Neo-rurality: the Benelux as a workshop for new ideas about threatened rural areas, Built Environment, 1, pp. 37-46. 
HAJER, M. (1995) The politics of environmental discourse, ecological modernisation and the policy process. Oxford: Clarendon Press.

HEALEY, P. (2006) Transforming governance: challenges of institutional adaptation and a new politics of space, European Planning Studies, 14, pp. 299-320.

HIDDING, M., NEEDHAM, D. \& WISSERHOF, J. (1998) Stad en land, een programma voor fundamenteel-strategisch onderzoek. NRLO-report 98/17. Den Haag: Nationale Raad voor Landbouwkundig Onderzoek.

HOLlidAY, J. (1994) The new urban realm, Town \& Country Planning, 10, pp. 259-261.

HOLLIDAY, J. (1997) Seeing the country whole, Town \& Country Planning, 7/8, pp. 200-201.

JANSSEN, J. (2006). Vooruit denken en verwijlen, de (re)constructive van het plattelandschap in Zuidoost-Brabant, 1920-2000. Tilburg: Stichting Zuidelijk Historisch Contact Tilburg.

JOUBERT, M. \& LIMBURG, R. (2009). Zoeken naar metropolitane landschapsparken in de Zuidvleugel. Bestuurlijk Platform Zuidvleugel.

KERKSTRA, K. (2004) De wereld een tuin, naar een postagrarisch cultuurlandschap, Blauwe Kamer, 1, pp. 54-57.

KESTELOOT, C. (2003) Verstedelijking in Vlaanderen : problemen, kansen en uitdagingen voor het beleid in de 21e eeuw, in L. SCHETS (eindred.) De eeuw van de stad, over stadsrepublieken en rastersteden: Voorstudies, pp. 15-39. Brussel: Ministerie van de Vlaamse Gemeenschap, Project Stedenbeleid.

LEINFELDER, H. (2005) Wordt het Parkbos de Gentse "Groenplaats"? Naar een alternatieve ruimtelijke perceptie van het buitengebied in de Vlaamse verstedelijkende 
samenleving, in: G. ALLAERT \& H. LEINFELDER (eds.) Parkbos Gent, over visievorming en beleidsnetwerking, pp. 41-58. Gent: Academia Press.

LEINFELDER, H. (2007) Dominante en alternatieve planningsdiscoursen ten aanzien van landbouw en open ruimte in een (Vlaamse) verstedelijkende context. Gent: Academia Press.

MACFARLANE, R. (1998) What - or who - is rural Britain? Town \& Country Planning, 5, pp. 184-188

MINISTERIE van de Vlaamse Gemeenschap (2004) Ruimtelijk Structuurplan Vlaanderen, gecoördineerde versie. Brussel: Afdeling Ruimtelijke Planning.

MUSACCHIO, L. (2008). Metropolitan landscape ecology, Landscape Jml., 1, pp. $1-8$.

MINISTERIE van de Vlaamse Gemeenschap (2005) Ruimtelijke visie voor landbouw, natuur en bos-regio Haspengouw-Voeren, gewenste ruimtelijke structuur. Brussel: Afdeling Ruimtelijke Planning.

NEWBY, H. (1996) Social change in rural England, Town \& Country Planning, 2, pp. 46-49.

OVERBEEK, G. (2006) Theoretical and methodological framework, in: G. OVERBEEK \& I. TERLUIN (eds.) Rural areas under urban pressure, case studies of rural-urban relationships across Europe, pp. 27-46. Wageningen: Landbouweconomisch Instituut.

OVERBEEK, G. \& TERLUIN, I. (2006) Introduction, in: G. OVERBEEK \& I.. TERLUIN (eds.) Rural areas under urban pressure, case studies of rural-urban relationships across Europe, pp. 21-26. Wageningen: Landbouweconomisch Instituut. 
SIEVERTS, T. (2003). Cities without cities: between place and world, space and time, town and country. London: Routledge.

VAN DEN BROECK, J. (2001) Central Belgium: a 'Park City'?: a policy based on deconcentrated clustering, paper at the international workshop New approaches to land management for sustainable urban regions, University of Tokyo, Tokyo, October 29-31 2001.

VAN DER PLOEG, J.D. (2000). The virtual farmer. Assen: Koninklijke Van Gorcum.

VAN DER PLOEG, J.D., LONG, A. \& BANKS, J. (eds.) (2002). Living countrysides, rural development processes in Europe: the state of the art. Doetinchem: Elsevier.

VAN EETVELDE, V. \& ANTROP, M. (2005). The signficance of landscape relic zones in relation to soil conditions, settlement pattern and territories in Flanders. Landscape and Urban Planning, 1-2, pp. 127-141.

VAN TATENHOVE, J., ARTS, B. \& LEROY, P. (2000) Introduction, in: J. VAN TATENHOVE, B. ARTS \& P. LEROY (eds.) Political modernisation and the environment, the renewal of environmental policy arrangements, pp. 1-15. Dordrecht: Kluwer Academic Publishers.

VERMEERSCH, C. (1989) Ruimtelijke planning, in: R. SENELLE (ed.) Ruimtelijke ordening en stedenbouw. Brugge: Die Keure.

ZONNEVELD, W. (1991). Conceptvorming in de ruimtelijke planning, patronen en processen. Planologische Studies 9A. Amsterdam: Planologisch en Demografisch Instituut van de Universiteit van Amsterdam.

ZONNEVELD, W. (1999) Stad/Land: visie op verstedelijking aan vernieuwing toe.

Katern bij Stedenbouw \& Ruimtelijke Ordening, 5, pp. 4-5. 
ZONNEVELD, W. \& VERWEST, F. (2005) Tussen droom en retoriek, de conceptualisering van ruimte in de Nederlandse planning. Rotterdam \& Den Haag: Nai Uitgevers \& Ruimtelijk Planbureau. 